\title{
Performance of Electric and Microwave Batch Plant Moisture Meters in Determining the Moisture Contents of Fine-Aggregate Materials for Concrete Production
}

by Willie E. McDonald, Toy S. Poole

U.S. Army Corps of Engineers

Waterways Experiment Station

3909 Halls Ferry Road

Vicksburg, MS 39180-6199

Final report

Approved for public release; distribution is unlimited

\footnotetext{
Prepared for U.S. Army Corps of Engineers

Washington, DC 20314-1000

Under Work Unit 31138
} 